\title{
Talon cusps - functional solution: a case report
}

\author{
Talon cusps - solução funcional: um relato de caso \\ Cúspides del talón - solución funcional: un informe de un caso \\ Alice Corrêa SILVA-SOUSA ${ }^{1}$ \\ Yara Teresinha Corrêa SILVA-SOUSA ${ }^{2}$ \\ Nathalia Cristina TAVELLA-SILVA ${ }^{3}$ \\ Marcelle DANELON ${ }^{4}$
}

${ }^{1}$ School of Dentistry, University of Ribeirão Preto (UNAERP), RibeirãoPreto, SP, Brazil; Student (Doctoral Degree) of Department of Restorative Dentistry, School of Dentistry of Ribeirão Preto, University of São Paulo (FORP-USP), Ribeirão Preto, SP, Brazil

${ }^{2}$ Titular Professor, School of Dentistry, University of Ribeirão Preto (UNAERP), 14096-900 Ribeirão Preto - SP, Brazil

${ }^{3}$ Student, School of Dentistry, University of Ribeirão Preto (UNAERP), 14096-900 Ribeirão Preto - SP, Brazil

${ }^{4}$ Department of Preventive and Restorative Dentistry, São Paulo State University (UNESP), School of Dentistry, Araçatuba - SP, Brazil, School of Dentistry, University of Ribeirão Preto (UNAERP), 14096-900 Ribeirão Preto - SP, Brazil

\begin{abstract}
Talon cusp is a rare dental anomaly that occurs more frequently in maxillary incisors and is defined as a projection in the area of the cincture of anterior teeth that extends from the cemento-enamel junction or the region of the cincture, following towards the incisal face. An eight-year-old female patient was referred to the University of Ribeirão Preto Pediatric Dentistry Clinic (UNAERP) with suspicion of a supernumerary tooth on the palatal surface of tooth 12 . During clinical and radiographic examination she found the presence of a conical-shaped enamel projection that presented a communication with the tooth 12 cincture and was thus classified as a talon cusp. Initially, prophylaxis and removal of the accumulated bacterial plaque were performed, verification of premature contact with paper for the joint and wear with a spherical diamond tip. FluroShield sealant was then applied following an adhesive protocol indicated by the manufacturer. After the necessary occlusal adjustments were made. 30 days later, the patient returned for clinical follow-up, reconversion and repolishing of the sealant. The talon cusp was diagnosed as Type I because it is morphologically well delineated and protrudes prominently from the palatal surface and extends at least halfway from the cemento-enamel junction to the incisal edge. It is recommended to seal the deep grooves to prevent caries. We can conclude that a rigorous clinical and radiographic examination leading to an early and accurate diagnosis is of extreme importance for the adoption of an adequate treatment.
\end{abstract}

Descriptors: Dental Abnormalities; Fused Teeth; Pediatric Dentistry.

\section{Resumo}

Talon Cúspide é uma rara anomalia dental que ocorre com maior frequência em incisivos superiores, sendo definida como uma projeção na área do cíngulo de dentes anteriores que se estende a partir da junção cemento-esmalte ou da região do cíngulo, seguindo em direção à face incisal. Paciente do gênero feminino, oito anos de idade, foi encaminhada à clínica de Odontopediatria da Universidade de Ribeirão Preto (UNAERP) com suspeita de dente supranumerário na face palatina do dente 12. Ao realizar o exame clínico e radiográfico constatou a presença de uma projeção de esmalte, de formato cônico, que apresentava comunicação com o cíngulo do dente 12, sendo assim, foi classificado como uma talon cúspide. Inicialmente foi realizado a profilaxia e remoção da placa bacteriana acumulada, verificação de contato prematuro com papel pra articulação e desgaste com ponta diamantada esférica. Na sequência, foi aplicado selante FluroShield seguindo protocolo adesivo indicado pelo fabricante. Após realizou-se ajustes oclusais necessários. 30 dias após, a paciente retornou para acompanhamento clínico, recontorno e repolimento do selante. O talon cúspide foi diagnosticado como sendo do Tipo I, pois é morfologicamente bem delineada que se projeta de forma proeminente da superfície palatina e se estende pelo menos metade da distância da junção cemento-esmalte até a borda incisal. Recomenda-se a realização do selamento dos sulcos profundos pra prevenção da cárie. Podemos concluir que é de extrema importância um exame clínico e radiográfico rigoroso que leve a um diagnóstico precoce e preciso, para adoção de um adequado tratamento.

Descritores: Anormalidades Dentárias; Dentes Fusionados; Odontopediatria.

\section{Resumen}

La cúspide del talón es una rara anomalía dental que se produce con mayor frecuencia en los incisivos maxilares y se define como una proyección en la zona del cíngulo de los dientes anteriores que se extiende desde la unión cemento-esmalte o la región del cíngulo, siguiendo hacia la cara incisal. Una paciente de ocho años fue remitida a la Clínica de Odontología Pediátrica de la Universidad de Ribeirão Preto (UNAERP) con la sospecha de un diente supernumerario en la superficie palatina del diente 12. Durante el examen clínico y radiográfico encontró la presencia de una proyección de esmalte de forma cónica que presentaba una comunicación con el cíngulo del diente 12 y, por lo tanto, se clasificó como un talón de cúspide. Inicialmente se realizó la profilaxis y la eliminación de la placa bacteriana acumulada, la verificación del contacto prematuro con el papel para la articulación y el desgaste con una punta de diamante esférica. Luego se aplicó el sellador FluroShield siguiendo un protocolo adhesivo indicado por el fabricante. Después de que se hicieran los ajustes oclusales necesarios. 30 días después, el paciente regresó para el seguimiento clínico, la reconversión y el repulido del sellador. El talón cúspide fue diagnosticado como Tipo I porque está morfológicamente bien delineado y sobresale de manera prominente de la superficie palatina y se extiende al menos hasta la mitad de la unión cemento-esmalte hasta el borde incisal. Se recomienda sellar los surcos profundos para prevenir la caries. Podemos concluir que un examen clínico y radiográfico riguroso que lleve a un diagnóstico temprano y preciso es de extrema importancia para la adopción de un tratamiento adecuado.

Descriptores: Anomalías Dentárias; Dientes Fusionados; Odontologia Pediátrica.

The talon cusp is an unusual developmental anomaly, which can be present in both primary and permanent dentition ${ }^{1-3}$. This projection can vary in size, number, shape and its formation can be composed only of enamel and dentin or even have pulp tissue projection ${ }^{4,5}$. The etiology of talon cusp is unknown, but suggest genetic and environmental factors ${ }^{6,7}$.

Appears in the morphodifferentiation phase, that is consequence of outward bulging on the inner enamel epithelial cells and focal hyperplasia of the mesenchymal peripheral cells of dental papilla ${ }^{8,9}$. 
Talon cusp was classified into 3 types by Hattab et al. ${ }^{8}$ : Type $\mathrm{I}$ is a talon, a morphologically well-delineated additional cusp that extends at least $50 \%$ of the inciso-cervical length of the tooth; Type II is a semitalon, a morphologically well-defined additional cusp that extends $25-50 \%$ of the tooth length; and type III is a trace talon, an enlarged or prominent cingulum, which occupies less than $25 \%$ of the distance from the cementoenamel junction to the incisal edge ${ }^{8,10}$. Other anomalies or syndromes may be present simultaneously with the talon cusp, such as dens in dente, tooth germination $^{11,12}$, Berardinelli-Seip ${ }^{13}$, Mohr, Rubinstein and Taybi, Ellis-van Creveld, SturgeWeber and incontinentia pigmenti achromians ${ }^{14}$.

The present study aimed to report a case and functional solution of talon cusp in a eight years old girl.

\section{CLINICAL CASE}

The patient's guardians previously authorized, through the informed consent form, the treatment performed, the documentation and subsequent publication. The pacient, female AVLF, eight years old, was referred to the Pediatric Dentistry Clinic of School of Dentistry, University of Ribeirão Preto, with suspicion of a supernumerary tooth in the palatal of tooth 12 , whose child complained of tooth movement (Figure 1).

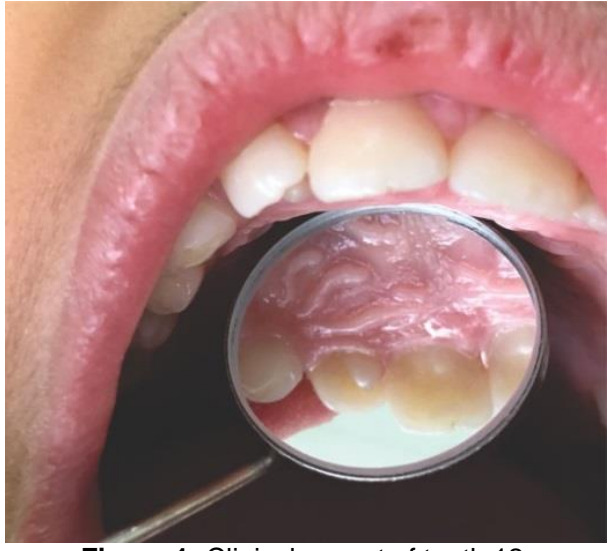

Figure 1: Clinical aspect of tooth 12

The clinical and radiographic examination was performed, and it was possible to observe the presence of a conical-shaped enamel projection in palatal side of lateral incisor that presented a communication with the tooth 12 cingulum, and was thus classified as a talon cusp (Figure 1 and Figure 2). Then, with a carbon sheet was checked for occlusion and observed the presence of premature contact on the talon cusp (Figure 3 ). It is recommended to seal the deep grooves to prevent dental caries. Thus, they were cleaned and prepared in a conservative way, only performing the wear in a minimally invasive way to remove the premature contact caused by this development with a delicately driven diamond spherical drill on a high speed motor (Figure 4). So the entire biofilm was then removed with a number 5 dentin spoon (Figure 5) and prophylaxis with Robson's brush and pumice.

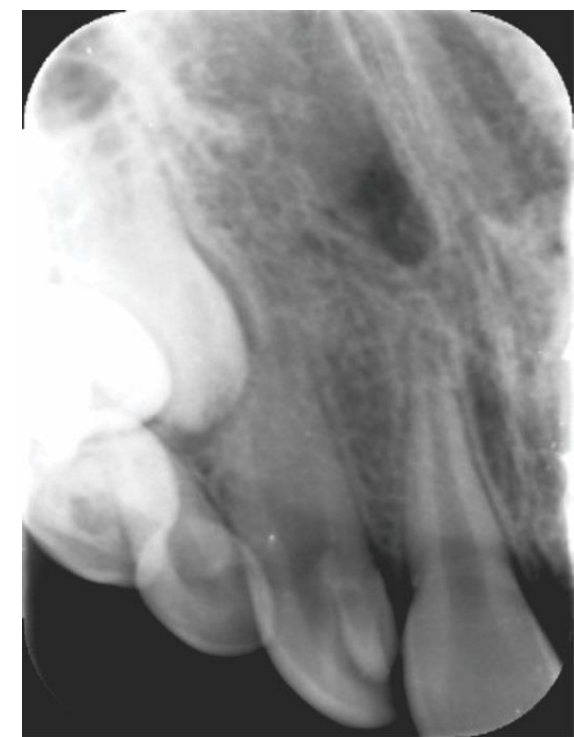

Figure 2: Radiographic aspect of tooth 12.

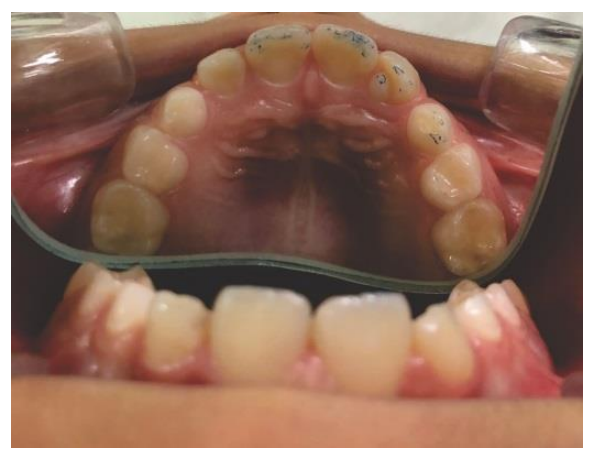

Figure 3: Inspection occlusion of tooth 12

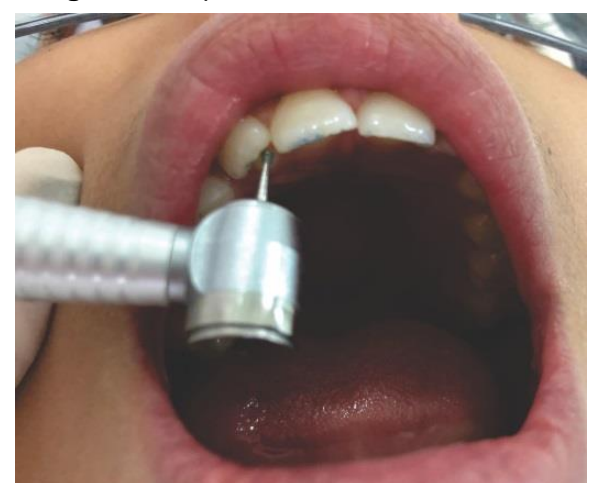

Figure 4: Minimal invasive wear in the cingle of tooth 12

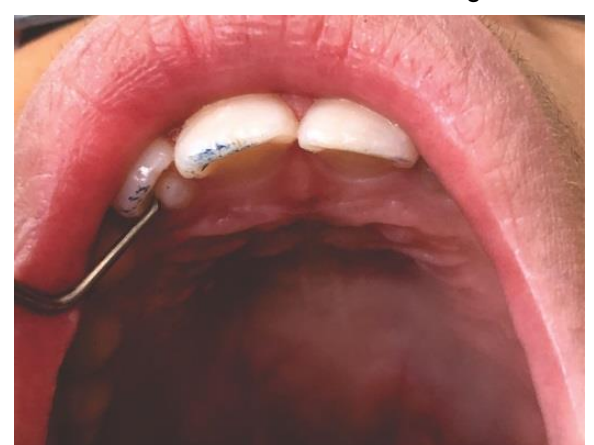

Figure 5: Removal of biofilm from tooth 12 with dentin spoon number 5 . 
FluroShield sealant (Dentsply International, York, PA, USA) was then applied following the adhesive protocol indicated by the manufacturer (Figure 6 and Figure 7). Finally, the necessary occlusal adjustments were made. After 30 days the patient returned for clinical follow-up and performance of the sealant (Figure 8).

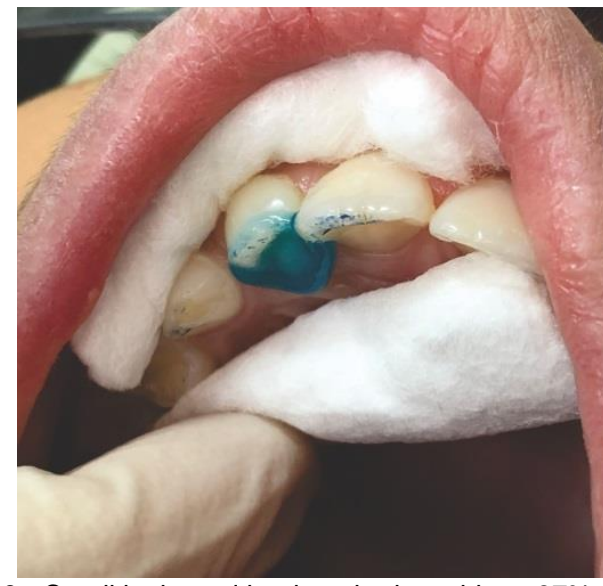

Figure 6: Conditioning with phosphoric acid at 37\% (Dentsply International, York, PA, USA) of the tooth 12.

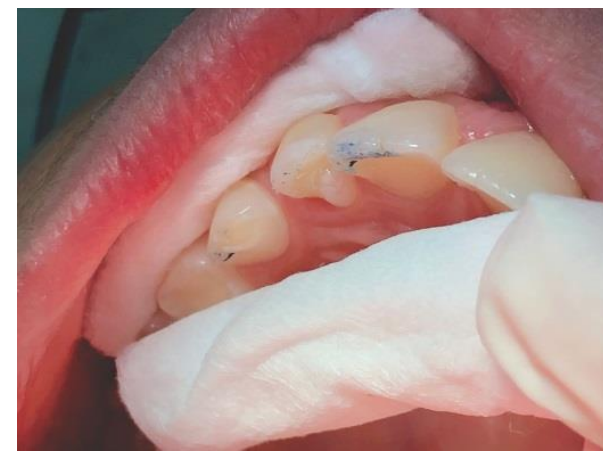

Figure 7: Application of Fluroshield sealant (Dentsply International, York, PA, USA) of the tooth 12.

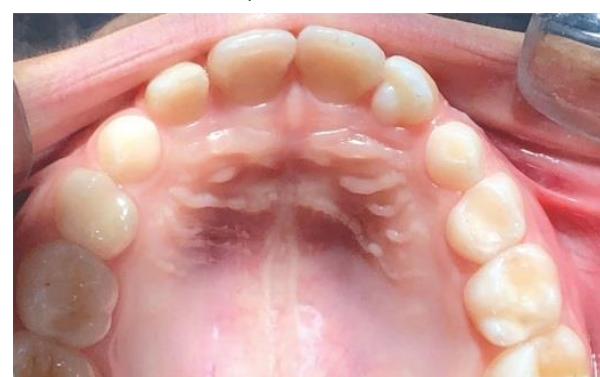

Figure 8: After 30 days-clinical follow-up and performance of the sealant of the tooth 12 .

The talon cusp was diagnosed as Type I because it is morphologically well delineated and protrudes prominently from the palatal surface and extends at least halfway from the cemento-enamel junction to the incisal edge ${ }^{8}$.

DISCUSSION

The talon cusp received this name due to its shape being similar to an eagle claw ${ }^{15-17}$. This anomaly in dental development is considered rare, its occurrence varies from $0.73 \%$ to $8 \%$ of the population ${ }^{16}$ and is characterized by the presence of an accessory structure projected from the cincture, or at the cemento-ename junction ${ }^{15,17-20}$ and can also be present in the posterior teeth, in the form of a cusp, called Evaginated Dens ${ }^{18}$. These projections may vary in shape, size and relationship with the incisal edge, depending on the projected extension, and are sufficient to hinder the occlusion and aesthetics of the individual ${ }^{17,18,21}$. In this case, the patient presented with a conical-shaped enamel projection, which presented communication with the tooth 12 cingulum, thus being classified as a talon cusp.

Histologically and radiographically, the presence of enamel, dentin and pulp ${ }^{15,17,20,21}$ can be observed. Radiographically, an image is considered poorly defined due to excessive growth of the dental crown, showing a V-shaped radiopaque area comprising enamel and dentin due to the overlapping of the cusp on the affected dental crown, making it difficult to see $^{15,19}$. Radiographic evaluation is important, despite the difficulty of visualization, as this anomaly can be mistaken for a supernumerary tooth or another anomaly, receiving the indication of unnecessary exodontia ${ }^{19}$. With suspicion of a supernumerary tooth and the presence of tooth movement, the patient was referred to the pediatric dentistry clinic and after a clinical and radiographic examination, the presence of the talon cusp was confirmed. The exact etiology is still unknown ${ }^{15,16}$. The literature suggests that the condition may have a multifactorial etiology ${ }^{16,18}$ as genetic ${ }^{9,19,21}$, ethnic $^{15,18}$ and environmental ${ }^{15,17,18,19}$ factors, performing the development of this anomalous structure ${ }^{15,19}$. According to Guven et al. ${ }^{19}$, it is related to disorders such as endocrine function impairment during the dental morphodifferentiation phase, resulting in the deployment of epithelial cells from enamel and focal hyperplasia of peripheral cells. Other authors suggest trauma during the development of the dental element as a contributing factor ${ }^{15}$, that in certain ethnic groups, such as the Chinese and Arab populations, there is an increase in this condition in relation to the others $^{15,18,19}$ and, that genetic influences on the formation of talon cusp were also suggested, in the evidence of its occurrence in relatives and twin brothers ${ }^{9,19,21}$. Although not documented as an important part of any specific syndrome, the talon cusp may occur alone or in association with other dental anomalies such as gemination, fusion, canine agenesis, supernumerary and impacted teeth, complex odontomas ${ }^{15,17,22}$. and occasionally, may be associated with syndromes such as Ellis-van Creveld, Rubinstein-Taybi, Sturge-Weber and Mohr ${ }^{15,17-20,23 .}$ In the present 
case, through anamense, clinical and radiographic examination, there were no reports relating the presence of the talon cusp with these factors.

According to Özkan et al. ${ }^{15}$, this anomaly is detected more frequently in males than females $(47: 26)^{15}$, contrary to what can be observed in this case. It can also be observed that this anomaly rarely appears on the vestibular side ${ }^{15,18,19}$, that most of the cases are unilateral $(90 \%)^{20}$; only $1 / 5$ of the cases are bilateral and affect the deciduous and permanent dentition ${ }^{22}$, being the most affected permanent (85\%), as demonstrated in the case described. In the present case, as in $92 \%$ of cases reported in the literature ${ }^{15}$. This anomaly was found in anterior teeth in the upper portion (91\%), which are more affected than the lower teeth $(9 \%)^{22}$. This condition has a predilection for maxillary lateral incisors (55\%) and maxillary central incisors (33\%), followed by mandibular canines (6\%) and maxillary canines $(4 \%)^{15,18,19}$. Hattab et al. ${ }^{8}$ proposed the classification of the talon cusp according to its shape and extension, being Type I (Claw), a morphologically well delineated cusp that projects at least half the distance from the cemento-enamel junction to the incisal edge, Type II (Half-claw), the cusp extends to less than half the length of the cemento-enamel junction to the incisal edge, and Type III (Claw-line), a prominent cincture that may have a conical, bifid or tuber-like appearance ${ }^{15,19,21}$. In this case, the patient had a morphologically well delineated cusp that projects at least half the distance from the cemento-enamel junction to the incisal edge on tooth 12, thus being classified as Type I, considered uncommon $(22.22 \%)$ in relation to the others ${ }^{19,21}$.

The correct diagnosis and classification of these disorders are fundamental in terms of complications and treatment options, as these anomalies have deep grooves and prominences ${ }^{15,22}$. The talon cusp can cause aesthetic alterations due to the presence, location and extent of the anomaly, predisposition to caries lesions due to food impaction and difficulty in hygiene and functional alterations such as occlusal traumas that can cause temporomandibular dysfunctions, periodontal alterations, pulpal exposures and periapical pathologies resulting from bite forces $^{15,18,20}$. The time of diagnosis alters the prognosis and the painful sensation of this condition, facilitating the necessary treatment ${ }^{17,22}$. Mader and Kellogg ${ }^{24}$ proposed that that talon cusp Type I present a greater pulpal extension, with a greater need for prevention $^{19}$. As observed in this case, after clinical and radiographic examination, it was observed the absence of aesthetic changes and the presence of functional changes due to premature contact, requiring occlusal adjustment and preventive therapy for deep fissures. Thus, they were cleaned and prepared in a conservative manner, performing only minimally invasive wear to remove premature contact caused by this development followed by sealing deep fissures to prevent caries, preventing future occurrences.

CONCLUSION

It can be concluded that a rigorous clinical and radiographic examination leading to an early and accurate diagnosis is of extreme importance for the adoption of adequate treatment.

REFERENCES

1. Nascimento BCS, Santos IMS, Fernandez MS, Viana VS. Cúspide em garra em paciente infantil com transtornos psicológicos: relato de caso. Arch Health Invest. 2021;10(1):134-39.

2. Coclete GA, Coclete GEG, Poi WR, Paulon SS, Pinto ZMPS, Salzedas LMP. Cúspide em garra. Arch Health Invest. 2015;4(2):5-8.

3. Gosselin ML, Doyle T, MacLellan J, Anderson RD, Dyment H. A Talon Cusp Mistaken for a Mesiodens: Case Report. J Can Dent Assoc. 2012;78:c6.

4. Tomazinho FS, Baratto-Filho F, Leonardi DP, Haragushiku GA, de Campos EA. Occurrence of talon cusp on a geminated maxillary central incisor: a case report. J Oral Sci. 2009; 51(2):297-300.

5. Hegde S, Shetty SR, Babu S. The reverse claw: Report of an extremely rare facial talon cusp. Dent Res J (Isfahan). 2012;9(5):638-39.

6. Oredugba FA. Mandibular facial talon cusp: case report. BMC Oral Health. 2005;5:9.

7. Sumer AP, Zengin AZ. An unusual presentation of talon cusp: a case report. $\mathrm{Br}$ Dent $\mathrm{J}$. 2005;199(7):429-30.

8. Hattab FN, Yassin OM, al-Nimri KS. Talon cusp in permanent dentition associated with other dental anomalies: review of literature and reports of seven cases. ASDC J Dent Child. 1996;63(5):368-76.

9. Elmubarak NA. Genetic Risk of Talon Cusp: Talon Cusp in Five Siblings. Case Rep Dent. 2019;2019:3080769.

10.Sarraf-Shirazi A, Rezaiefar M, Forghani M. A rare case of multiple talon cusps in three siblings. Braz Dent J. 2010;21(5):463-66.

11. Gunduz K, Acikgoz A. An unusual case of talon cusp on a geminated tooth. Braz Dent J. 2006;17:343-46.

12. Siraci E, Gungor HC, Cehreli ZC. Dens 
invaginatus and talon cusp co-occurring in a mandibular central incisor: a case report. J Dent Child (Chic). 2008;75(2):177-80.

13. Solanki M, Patil SS, Baweja DK, Noorani H, Pk S. Talon cusps, macrodontia, and aberrant tooth morphology in Berardinelli-Seip syndrome. Oral Surg Oral Med Oral Pathol Oral Radiol Endod. 2008;105(1):e41-7.

14. Rayen R, Muthu MS, Sivakumar N. Aberrant talon cusps: report of two cases. J Indian Soc Pedod Prev Dent. 2006;24(Suppl 1):S7-10.

15. Özkan G, Toptaş A, Güneri P. The characteristics and occurrence of the talon cusps in Turkish population: a retrospective sample study. Surg Radiol Anat. 2016;38(9):1105-1110.

16. Sudhakar S, Madhavan A, Balasubramani S, Shreenivas S. A Rare Familial Presentation of Facial Talon Cusp. J Clin Diagn Res. 2017;11(1):ZD15-ZD17.

17. Kv S, C PR, Yadav SR, Kumar N, C D MK, Kumar SP. Multiple talon cusps on maxillary central incisor: A case report. J Dent Res Dent Clin Dent Prospects. 2017;11(2):127-30.

18. Dunn WJ. Unusual case of labial and lingual talon cusps. Mil Med. 2004;169(2):108-10.

19. Guven Y, Kasimoglu Y, Tuna EB, Gencay K, Aktoren O. Prevalence and characteristics of talon cusps in Turkish population. Dent Res J (Isfahan). 2016;13(2):145-50.

20. Raviraj J, Suman V, Suresh D, Kartik K. Achondroplasia with multiple supplemental supernumerary teeth and multiple talon cusps: A rare case report. Dent Res J (Isfahan). 2017;14(3):219-22.

21. Leith R, O'Connell AC. Selective Reduction of Talon Cusps- A Case Series. J Clin Pediatr Dent. 2018;42(1):1-5.

22. Tarım Ertaş E, Yırcalı Atıcı M, Arslan H, Yaşa $B$, Ertaş $H$. Endodontic treatment and esthetic management of a geminated central incisor bearing a talon cusp. Case Rep Dent. 2014;2014:123681.

23. Gunashekhar M, Hameed MS, Bokhari SK. Oral and dental manifestations in Rubinstein-Taybi syndrome: report of a rare case. Prim Dent Care. 2012;19(1):35-8.

24. Mader CL, Kellogg SL. Primary talon cusp. ASDC J Dent Child. 1985;52(3):223-26.

\section{CORRESPONDING AUTHOR}

\section{Marcelle Danelon}

School of Dentistry,

University of Ribeirão Preto - UNAERP

Av Costábile Romano 2.201

14096-900 Ribeirão Preto - SP, Brazil

Tel. +551636036717

Email: marcelledanelon@hotmail.com
Received 17/06/2020

Accepted 14/04/2021

\section{CONFLICTS OF INTERESTS}

The authors declare no conflicts of interests. 